Baseline

\title{
Hydrogeochemical and isotopic signature of surface and groundwater in a highly industrialized sector of the Rio de la Plata coastal plain (Argentina)
}

\author{
L. Santucci ${ }^{\text {a,* }}$,E. Carol $^{\text {a }}$, G. Borzi ${ }^{\mathrm{a}}$, M.G. García ${ }^{\mathrm{b}}$ \\ a Centro de Investigaciones Geológicas (CIG), Consejo Nacional de Investigaciones Científicas y Técnicas (CONICET) - Universidad Nacional de La Plata (UNLP), Calle 64 \\ y Diag, 113, 1900 La Plata, Buenos Aires, Argentina \\ b Centro de Investigaciones en Ciencias de la Tierra (CICTERRA), CONICET, and FCEFyN Universidad Nacional de Córdoba, Córdoba, Argentina
}

\section{A R T I C L E I N F O}

\section{Keywords:}

Heavy metals

Environmental isotopes

Hydrochemistry

Petrochemical pole

Río de la Plata estuary

\begin{abstract}
A B S T R A C T
The coastal plain of the middle estuary of the Río de la Plata is a highly industrialized area and is densely populated by sectors. The main human activity in the sector encompassed between the cities of Ensenada and Berisso is associated with the petrochemical industry. In this work, hydrogeochemical and isotopic characteristics of surface and groundwater in the impacted area are analyzed and the results are contrasted with those obtained in an undisturbed protected area. Major and trace elements were determined using standardized methods while the stable isotopes $\delta^{18} \mathrm{O}$ y $\delta^{2} \mathrm{H}$ were analyzed by mass spectroscopy. Human impact is evidenced by the occurrence of large variations in the major chemical composition of water, and also by the elevated concentrations of some trace elements that are not contributed from natural sources. These results may contribute to the understanding of chemical processes and pollutants distribution in highly industrialized coastal plain areas.
\end{abstract}

Coastal plains are complex hydrological environments where the chemical composition of water is controlled by multiple natural factors such as regional discharge, rainfall, tides, and evapotranspiration (e.g., Vandenbohede and Lebbe, 2012; Da Lio et al., 2015). In addition, these regions located at the interface between oceans and the continents are highly stressed owing to their intensively use and the accumulation of the byproducts of inland human activities, that are discharged from rivers and atmospheric deposition (Pruden et al., 2006; Da et al., 2014; Wu et al., 2014; Zhu et al., 2017; Herlinger and Viero, 2007; Graber et al., 2008; Güler et al., 2012). Therefore, an integrated understanding of fundamental physical and chemical processes is required to manage coastal resources more efficiently, based on site-specific comparative studies of coastal environments.

Modifications to the hydrological functioning and to the water quality are commonly registered in coastal plains with industrial development worldwide (e.g., Vecchioli, 1998; Herlinger and Viero, 2007; Botté et al., 2010; Marcovecchio et al., 2010; La Colla et al., 2015; Sá et al., 2015). The coastal plain of the Río de la Plata is one of the most extensive of the Atlantic coast of South America. Its hydrochemical characteristics have been mostly studied in pristine areas (e.g. Logan and Rudolph, 1997; Logan and Nicholson, 1998; Carol et al., 2009; Carol et al., 2013) while just a few local works have been performed in industrialized sectors. Thus, in this work the hydrogeo- chemical characterization of groundwater highly affected by the discharge of effluents derived from the petrochemical pole located between Berisso and Ensenada cities (Fig. 1) is performed, with the aim of contributing to the knowledge of the water chemical composition in impacted areas of the Río de la Plata coastal plain. The obtained results are contrasted with those of a pristine sector located in the Punta Lara Natural Reserve in order to assess the impact of the industrial activity.

The study area is located between the cities of Ensenada and Berisso and corresponds to a $\sim 10 \mathrm{~km}$ wide coastal strip, formed on the right margin of the middle Río de la Plata estuary (Fig. 1). The estuary has a semidiurnal, microtidal regime, with water salinity varying in this section between 1.0 and $2.0 \mathrm{~g} \mathrm{~L}^{-1}$ (Kind, 2004). Climate in the area is mild and humid with annual rainfall averaging $1010 \mathrm{~mm} \mathrm{yr}^{-1}$ (period: 1900-2012) and a mean annual temperature of $16.2^{\circ} \mathrm{C}$ (Carol et al., 2012).

The coastal plain is bounded by the Río de la Plata in the East and by the Pleistocene loess plain in the West (Schnack et al., 2005). Clayedsilty sediments deposited in the tidal plain cover most parts of the study area and they are overlain by present-day alluvial deposits of the levee in the vicinity of the Río de la Plata (Fig. 1). In the Punta Lara Natural Reserve the geological, hydrological and environmental characteristics are preserved from human alterations. In this protected area, the main water course is Las Cañas stream which crosses the zone following a

\footnotetext{
* Corresponding author.

E-mail address: luciasantucci@fcnym.unlp.edu.ar (L. Santucci).
} 


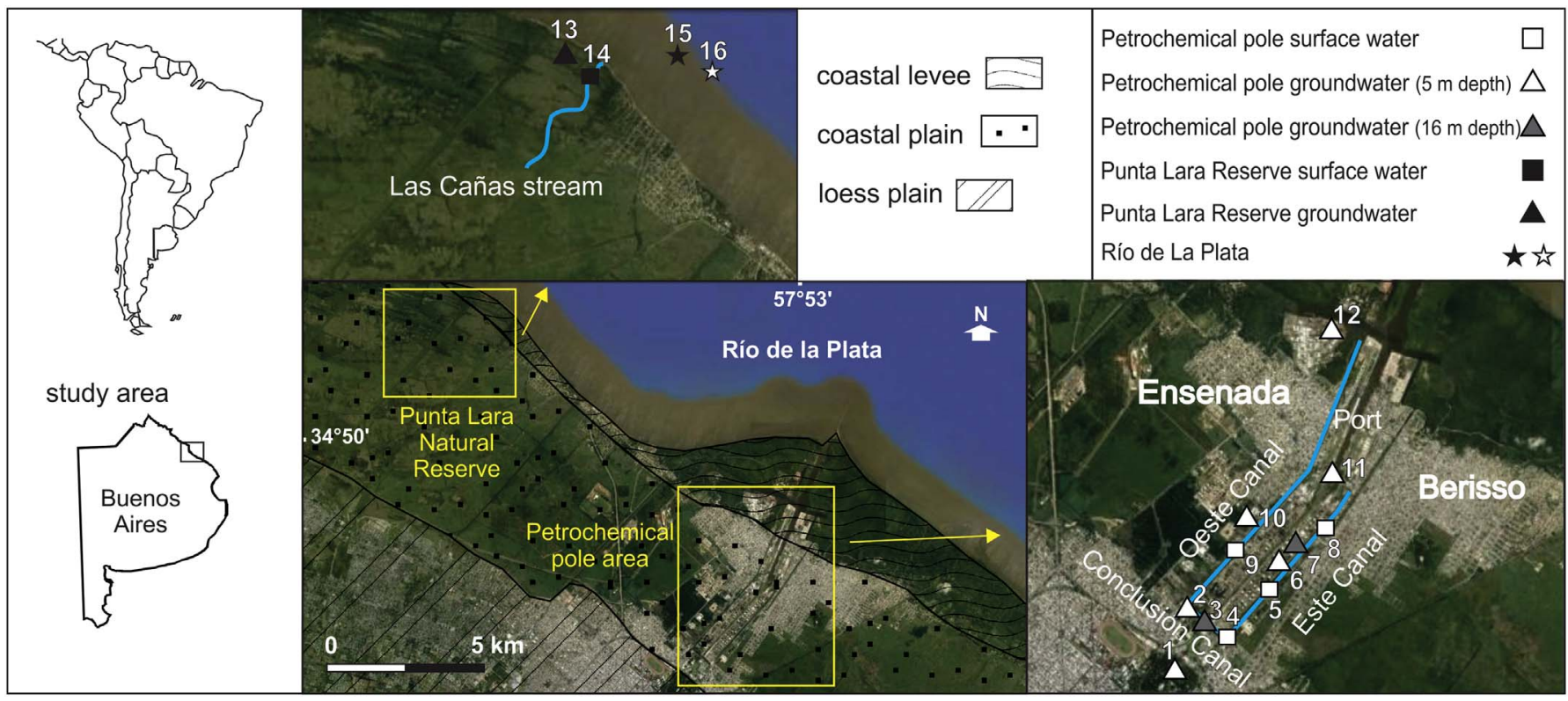

Fig. 1. Map of the study area and location of sampling points.

SW-NE direction and finally discharges into the Río de la Plata (Fig. 1). The Punta Lara Natural Reserve is the only pristine area in this urbanized and industrialized sector where one of the biggest ports and refineries of Argentina were emplaced since the early 1920s (Fig. 1). The petrochemical pole occupies an area of about 605 ha transversal to the Río de la Plata coast and is limited by three canals (Conclusión, Este, and Oeste) and by the La Plata port, located in the North. Because the area was originally affected by continuous flooding, it has been elevated for nearly $2 \mathrm{~m}$ above the natural level with loessic sediments during the construction of the petrochemical pole.

Surface water samples were collected in 2015 from the three canals dug around the petrochemical pole (Conclusión, Este and Oeste), while groundwater samples were collected from exploration boreholes drilled on the margins of the canals (Fig. 1). In the Punta Lara Reserve, surface water samples were collected from Las Cañas stream, while groundwater was sampled from an exploration borehole drilled a few meters northward the stream. Most of the sampled boreholes were manually drilled and fitted with a 4-in. PVC casing, with grooved filter and a siliceous gravel prefilter. Deeper boreholes located near the Conclusión and Este canals (16 $\mathrm{m}$ depth) were drilled using a water circulation rotary drill, and built as described above. A detailed record of the lithological and mineralogical characteristics of the sediment layers penetrated by the boreholes was performed during well logging. In addition to surface and groundwater samples collected in the study sector of the Río de la Plata coastal plain, two water samples were collected in the Río de la Plata in order to evaluate the influence of the tidal flow on the chemical composition of water in the coastal plain.

Field determinations consisted of $\mathrm{pH}$ and electrical conductivity (EC). In the Punta Lara Natural Reserve periodic measures of $\mathrm{pH}$ and EC were recorded along the Las Cañas stream, from the catchments to its mouth. After collection, samples were filtered through $0.22 \mu \mathrm{m}$ cellulose acetate membrane filters (Millipore Corp.). The filtration equipment was repeatedly rinsed with sample water prior to filtration. The aliquots used for trace elements determination $(15 \mathrm{ml})$ were acidified to $\mathrm{pH}<2$ with ultrapure $\mathrm{HNO}_{3}$ ( $>99.999 \%$, redistilled, Aldrich Chemical) and stored in pre-cleaned polyethylene bottles. A $1000 \mathrm{ml}$ aliquot was stored in polyethylene bottles, without acidifying, at $4{ }^{\circ} \mathrm{C}$ for the determination of major ions. Unfiltered samples were stored in $500 \mathrm{ml}$ polyethylene bottles at $4{ }^{\circ} \mathrm{C}$, for stable isotopes determinations.

Determinations of major ions $\left(\mathrm{HCO}_{3}{ }^{-}, \mathrm{Cl}^{-}, \mathrm{SO}_{4}{ }^{-2}, \mathrm{Ca}^{+2}, \mathrm{Mg}^{+2}\right.$, $\mathrm{Na}^{+}, \mathrm{K}^{+}$) were performed following standard methods outlined by the
American Public Health Association (APHA, 1998). Calcium was determined by titration using a 0.01 M EDTA solution, and Magnesium was calculated as the difference between total hardness and calcium expressed as $\mathrm{CaCO}_{3}$. Sodium and potassium were determined by flame photometry using a Metrolab 315 photometer. Chloride was determined by titration using the argentometric method. Sulphate was precipitated in an acetic acid medium with $\mathrm{BaCl}_{2}$ and its concentration was determined by turbidimetry. Bicarbonate and carbonate were determined by titration using a $0.01 \mathrm{~N}$ sulfuric acid solution and methyl-orange and phenolphthalein were used as end-point indicators, respectively. Ion balances were typically lower than $10 \%$ in all cases.

Minor and trace elements were measured by ICP-MS (Perkin Elmer Sciex Elan 6000 - quadrupole mass spectrometer). The validity of the results for major and trace elements were checked with NIST-1643e (Trace Elements in Water Reference Material certified by the National Institute of Standards \& Technology, USA) and SRLS-5 (River Water Reference Material for Trace Metals certified by the National Research Council of Canada), carried out along with sample analysis. The accuracy of standard measures ranged between 1 and $10 \%$ in both cases. In addition, duplicated analysis were performed every 10 samples in order to check the reproducibility of results, and the precision ranged between 1 and $8 \%$ in all analyzed elements. Isotope ratios $\delta^{18} \mathrm{O}$ and $\delta^{2} \mathrm{H}$ were measured using mass spectroscopy (Thermo Finnigan MAT Delta Plus XL continuous flow mass spectrometer). The analytical accuracy is $\pm 0.05 \%$ and $\pm 0.3 \%$, for $\delta^{18} \mathrm{O}$ and $\delta^{2} \mathrm{H}$, respectively. Results are reported in $\delta$ (\%) relative to V-SMOW (Gonfiantini, 1978).

The lithological and textural descriptions carried out during drilling show that the unconfined aquifer in the loess plain region is composed of silty to silty-clayed sediments with calcium carbonate concretions. The mean aquifer thickness is $31.5 \mathrm{~m}$ and it generally wedges out towards the Río de la Plata. In the coastal plain, the unconfined aquifer corresponds to $\sim 6 \mathrm{~m}$ thick silty to clayed sediments that alternate with lenses of fine-grained sands and marine shells deposited over the loess sediments (Fig. 2). In the petrochemical pole groundwater is also in contact with the $2 \mathrm{~m}$ thick sediments that fill the area. Finally, the uppermost sediments consist of fine-grained sands corresponding to alluvial deposits of the levee in the vicinity of the Río de la Plata. In both, the loess plain as well as in the coastal plain, the unconfined aquifer overlays a $3 \mathrm{~m}$ thick silty-clayed layer which hinders the hydraulic transmission between the unconfined aquifer and the under- 


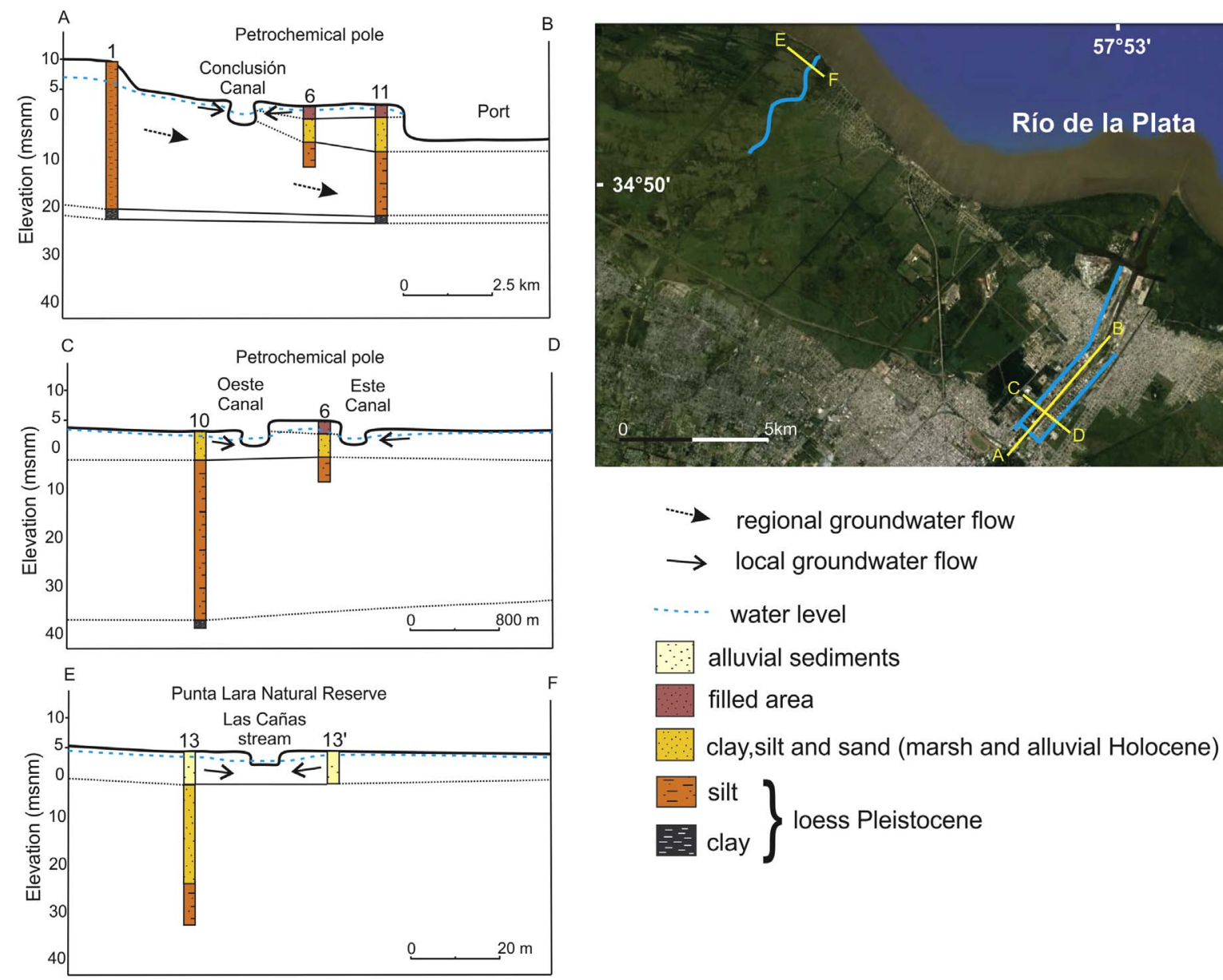

Fig. 2. Schematic cross section of the study area showing the regional and local flow paths and the identified aquifers.

lying semi-confined aquifer. Water table depths vary between $9.60 \mathrm{~m}$ b.s. (meters below surface) in the loess plain to $1.41-0.37 \mathrm{~m}$ b.s. in the vicinity of the Río de la Plata. According to water table records, the regional groundwater flow is towards the Río de la Plata (Fig. 2), while local groundwater mainly discharges into Las Cañas stream and the canals dug in the petrochemical sector (Fig. 2).

The physico-chemical parameters and the concentration of major ions and selected trace elements measured in surface and groundwater samples are shown in Table 1. Surface water in the Punta Lara Reserve is slightly alkaline (pH 7.9) and moderately diluted (EC $668 \mu \mathrm{Sm}^{-1}$ ). The periodic records of $\mathrm{pH}$ and EC in the stream indicated that $\mathrm{pH}$ values range between 6.8 and 7.9 while EC vary between 410 and $732 \mu \mathrm{S} \mathrm{cm}^{-1}$. The major chemical composition at the stream discharge into the Río de la Plata is dominated by $\mathrm{Cl}^{-}$and $\mathrm{Na}^{+}$ions with subordinated $\mathrm{HCO}_{3}{ }^{-}$(Fig. 3; sample 14). This chemical signature coincides with the major ion composition determined in the Río de la Plata during high tides (Fig. 3; sample 16) but the salinity content in the Río de la Plata is higher (EC $1092 \mu \mathrm{S} \mathrm{cm}^{-1}$ ). When water discharge contributions from the Río de la Plata main tributaries are higher, the river major chemical composition changes to $\mathrm{Na}-\mathrm{HCO}_{3}$ (Fig. 3; sample 15), the salinity content is lower (EC $392 \mu \mathrm{S} \mathrm{cm}^{-1}$ ) and $\mathrm{pH}$ slightly increases ( $\mathrm{pH}$ 8.1).

In the coastal areas that are flooded during high tide events, the chemical composition of groundwater is similar to that of the Río de la Plata, showing a dominant Na-Cl composition in the coastal levee (sample 12) and a $\mathrm{Na}-\mathrm{Cl} / \mathrm{SO}_{4}{ }^{-2}$ composition in the reserve (sample 13). However in the reserve the $\mathrm{pH}$ is rather more acidic than in the Río de La Plata, with values that range between 4.4 and 6.7.
Surface water of the petrochemical pole, is slightly alkaline and their chemical composition is dominated by $\mathrm{Na}^{+}$and $\mathrm{HCO}_{3}{ }^{-}$ions (Fig. 3). Unlike surface water of the Río de la Plata and Las Cañas stream, water in the canals of the petrochemical pole are more saline, with EC values ranging between 1793 and $941 \mu \mathrm{cm}^{-1}$ (Table 1). Groundwater in the industrial sector is of the $\mathrm{Ca} / \mathrm{Mg}-\mathrm{HCO}_{3}$ (samples 2 and 10; Fig. 3), $\mathrm{Na}^{-} \mathrm{HCO}_{3}$ (samples 3, 6, 7, and 11) and Na-Cl types (sample 1), and in all cases, waters are alkaline (average $\mathrm{pH}$ 8.27). The variability in the major chemical composition depends on the aquifer depth and location of the boreholes. EC values are also variable in this sector; near the Oeste and Conclusión canals, EC vary from 588 to $2950 \mu \mathrm{sm}^{-1}$, while the highest EC values were measured in groundwater close to the Este canal (samples 6 and 7; Fig. 3), where a relatively important concentration of $\mathrm{SO}_{4}{ }^{-2}$ has been measured (Table 1). Bivariate plot in Fig. 4 a also reveal that $\mathrm{Na}^{+}$contents measured in groundwater samples of the petrochemical pole generally increase (up to near $40 \mathrm{mmol} / \mathrm{L} \mathrm{Na}^{+}$) with increasing $\mathrm{H}_{4} \mathrm{SiO}_{4}$, while a less marked trend is observed in the $\mathrm{Ca}^{+2}$ vs. $\mathrm{H}_{4} \mathrm{SiO}_{4}$ and $\mathrm{Mg}^{+2}$ vs. $\mathrm{H}_{4} \mathrm{SiO}_{4}$ plots $\left(\mathrm{Ca}^{+2}\right.$ and $\mathrm{Mg}^{+2}$ values less to $5 \mathrm{mmol} / \mathrm{L}$; Fig. $4 \mathrm{~b}$ and c). A 1:1 ratio linear trend that involves positive values of $\mathrm{Na}^{+}-\mathrm{Cl}^{-}$ associated with negative values of $\left(\mathrm{Ca}^{+2}+\mathrm{Mg}^{+2}\right)-\left(\mathrm{HCO}_{3}{ }^{-}+\mathrm{SO}_{4}{ }^{-2}\right)$ is followed by most samples (except sample 6), which reveals that excesses of $\mathrm{Na}^{+}$are coupled with $\mathrm{Ca}^{+2}$ and $\mathrm{Mg}^{+2}$ deficiencies (Fig. 5).

The concentration of some trace elements, such as $\mathrm{Cu}, \mathrm{V}$, As, $\mathrm{Zn}, \mathrm{Mn}$ and $\mathrm{Cr}$ are elevated and in some cases, they are above the national guideline values for drinking water (CAA, 2012) in some specific sectors of the study area (Table 1). Even though surface and groundwater are not used for human supply, these guidelines serve as a 


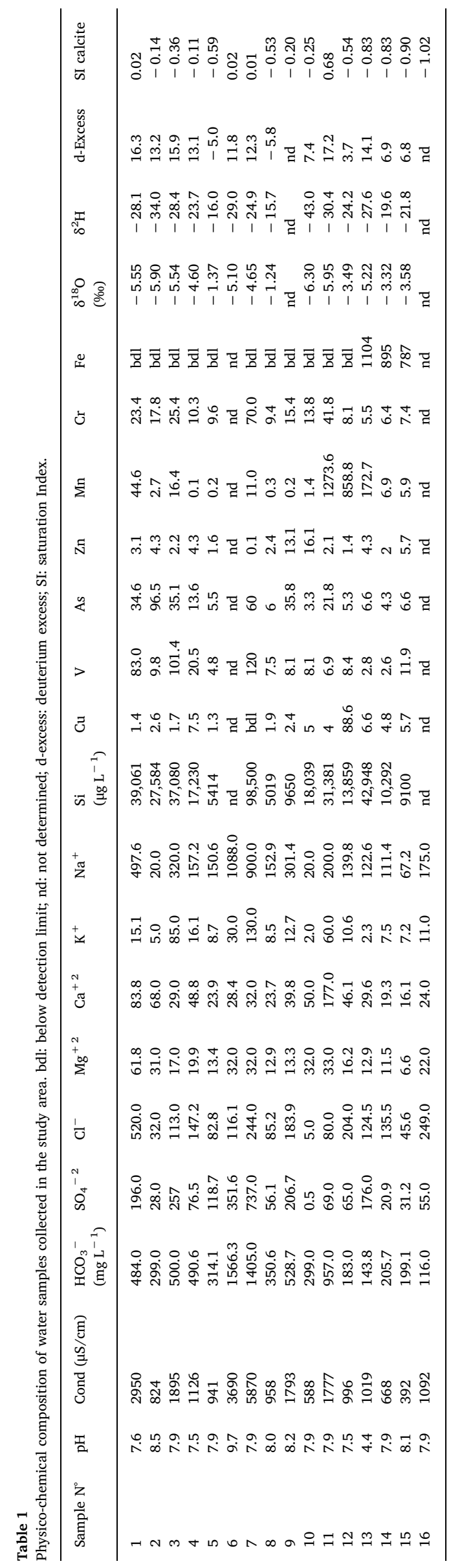

reference for water quality in the study area. Considering all samples, concentrations of $\mathrm{Cu}$ vary between 1.3 and $88.6 \mu \mathrm{g} \mathrm{L}{ }^{-1}$, the highest value being measured in the groundwater sample collected in the coastal levee. The concentration of geogenic contaminants such as As and $\mathrm{V}$ range between 3.3 and $96.5 \mu \mathrm{g} \mathrm{L}^{-1}$, and between 2.6 and $120 \mu \mathrm{g} \mathrm{L}^{-1}$ respectively, and the highest values were determined in groundwater samples collected near the Conclusión and Este canals in the petrochemical pole. Concentrations of $\mathrm{Cr}$ vary from 5.5 to $41.8 \mu \mathrm{g} \mathrm{L}^{-1}$; higher concentrations were determined near the Este canal and in the groundwater sampled in the port. Concentrations of Zn measured in both, surface and groundwater samples collected near the Oeste canal were about three to four times higher than those measured in the remaining samples, while high concentrations of Mn, exceeding the guideline value for drinking water (i.e., $0.10 \mathrm{mg} \mathrm{L}^{-1}$ ) were determined in the coastal levee near the petrochemical pole and in the port area (Table 1). Interestingly, high concentrations of soluble Mn and $\mathrm{Fe}$ were measured in groundwater samples collected from the reserve sector.

The stable isotopic composition of surface and groundwater samples collected in the study area is shown in Table 1 . The values of $\delta^{18} \mathrm{O}$ measured in surface water varied between $-4.60 \%$ and $-1.24 \%$, while $\delta^{2} \mathrm{H}$ ranged between $-23.7 \%$ and $-15.7 \%$. In groundwater samples, the corresponding values varied between $-6.30 \%$ and $-3.49 \%$, and $-43.0 \%$ and $-24.2 \%$ for $\delta^{18} \mathrm{O}$ and $\delta^{2} \mathrm{H}$ respectively. Fig. 6 a shows the isotopic signature of the surface and groundwater samples analyzed in this study. Most groundwater samples (samples 10, $2,11,1,3,13,6$ and 7) as well as surface water samples of the Conclusión canal plot over the Local Meteoric Water Line (LMWL), defined as $\delta^{2} \mathrm{H}=8 \delta^{18} \mathrm{O}+14$ (Dapeña and Panarello, 2004). Conversely, groundwater samples collected from the coastal levee - with an isotopic content similar to that of the Río de la Plata - as well as the sample collected from the Las Cañas stream in the Punta Lara reserve plot below the LMWL suggesting that they were affected in some extent by evaporation. Surface water of the Este canal is isotopically enriched due to evaporation and shows negative deuterium excess values (Table 1).

In the pristine sectors of the coastal plain, flooding by tidal events is recurrent and thus, it strongly controls the chemical composition of surface and groundwater (Carol and Kruse, 2012; Carol et al., 2013). In agreement, the chemical and isotopic signature of Las Cañas stream, the groundwater in pristine areas of the coastal plain, and the Río de la Plata are rather similar. In particular, deuterium excess values are nearly identical in samples collected from the Las Cañas stream and Río de la Plata (6.9 and 6.8 respectively, Table 1 ). In addition, the isotopic composition of the Río de la Plata could shows periodic variations because it depends on meteorological factors as well as on contributions from its tributaries (Panarello and Dapeña, 2009). In spite of the similarities observed, some differences arise due to natural factors such as the dilution of groundwater associated with rainfall recharge, and the organic matter decomposition in the areas occupied by the riverside jungle that produces slightly acidic and reductive conditions. This explains the elevated concentrations of $\mathrm{Mn}$ and $\mathrm{Fe}$ measured in groundwater of the reserve and the presence of soil mottling features in the area (López-Lanús and Marino, 2010). Moreover, the concentration of sulphate in the Punta Lara reserve groundwater (sample 13) is higher than the corresponding values measured in the Río de la Plata (samples 15 and 16) and in the levee (sample 12). Previous studies carried out in coastal areas close to the study area suggested that these higher contents are likely due to the oxidation of sedimentary pyrite spread in the vadose zone (Logan et al., 1999; Logan and Nicholson, 1998). Therefore, alternating oxidizing and reducing conditions should likely control the presence of high concentrations of sulphate and dissolved metals (i.e., $\mathrm{Mn}$ and Fe) in the coastal plain groundwater.

In the petrochemical sector, landfill and piping resulted in strong modifications to the hydrodynamics and sedimentary conditions of the coastal plain that have limited the influence of flood tides and altered 

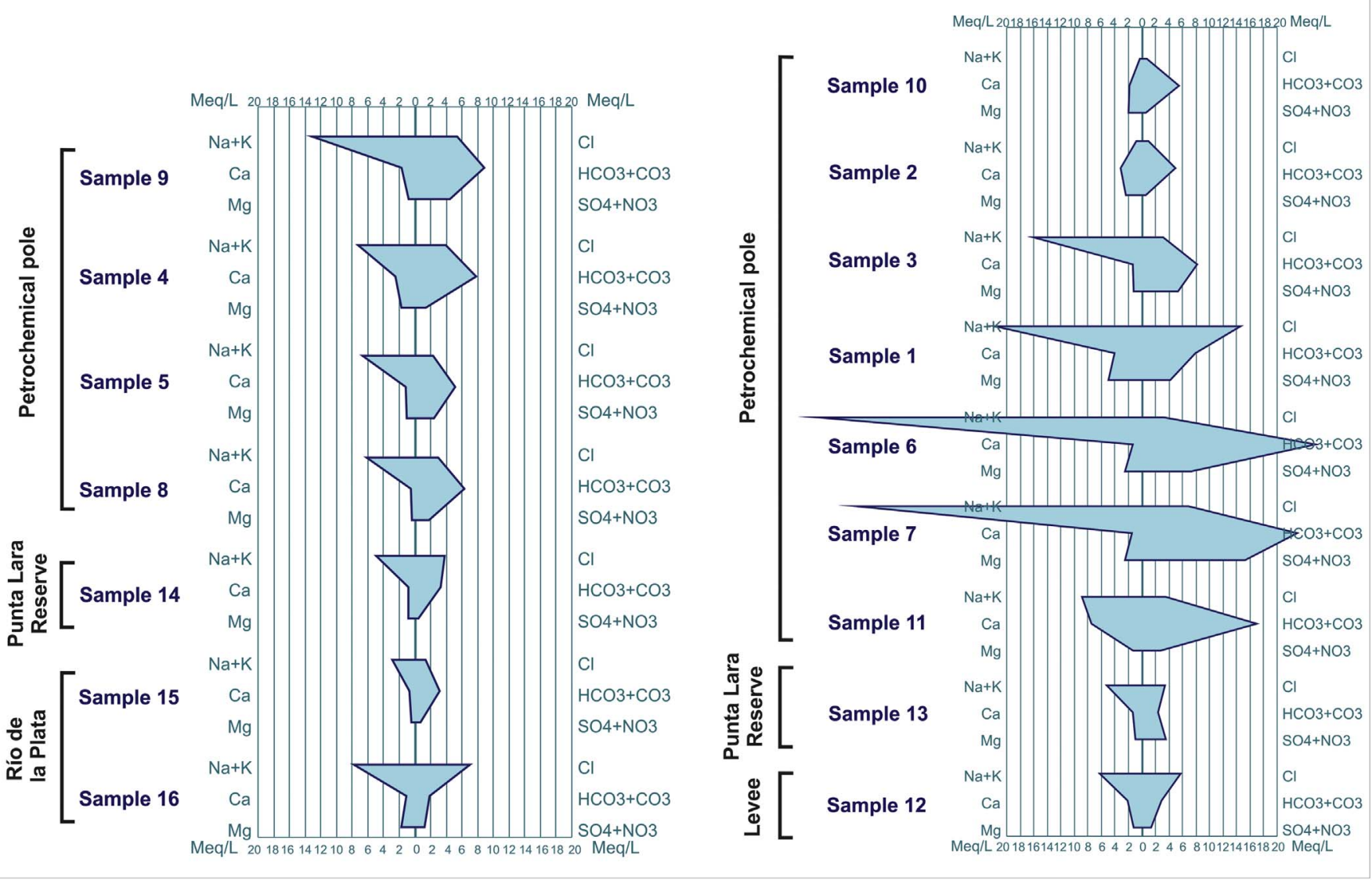

Fig. 3. Stiff diagrams showing the major chemical composition of surface water (left) and groundwater (right) of the study area.

the chemical and mineralogical composition of the sedimentary substrate. As a consequence, the chemical signature of groundwater in this sector is being modified by reactions with sediments different to those of the coastal plain as well as by effluent infiltration. The influence of the carbonate-rich loess landfill likely conditions the $\mathrm{Ca} / \mathrm{Mg}-\mathrm{HCO}_{3}$ type signature of groundwater in this sector of the study area. The dissolution of carbonates is enhanced by the slightly acidic $\mathrm{pH}$ values of the rainfall that recharges the unconfined aquifer as suggested by water isotopes (Fig. 6 a) and supported by the negative saturation index (SI) of calcite calculated for most samples in this part of the study area (Table 1). In addition, calcite dissolution can also be inferred from the bivariate plots in Fig. 6, where increasing $\mathrm{Ca}^{+2}$ and $\mathrm{HCO}_{3}{ }^{-}$concentrations at nearly constant $\delta^{18} \mathrm{O}$ values are observed in groundwater samples of the petrochemical pole.

As suggested by the bivariate plots in Fig. $6 \mathrm{~b}-\mathrm{h}$, some other minerals may control the chemical composition of water in the study sector of the coastal plain. The mineralogical composition of the unconfined aquifer is dominated by the presence of silicates, while in the loess plain sector abundant volcanic glass shards were reported. Thus, all these mineral phases may likely contribute solutes to groundwater. For example, the alteration of silicates can be represented by the general reaction (1).

Silicate $+\mathrm{H}_{2} \mathrm{O}+\mathrm{CO}_{2}=$ clay mineral $+\mathrm{HCO}_{3}{ }^{-}+\mathrm{H}_{4} \mathrm{SiO}_{4}+$ cations

According to Eq. (1), the weathering of silicates leads to the formation of clay minerals and releases $\mathrm{H}_{4} \mathrm{SiO}_{4}, \mathrm{HCO}_{3}{ }^{-}$and alkaline and alkaline-earth cations to water. In consequence, a positive linear trend between the released ions should be expected in systems dominated by silicate weathering. Indeed, this trend is observed between dissolved $\mathrm{Si}$ (expressed as $\mathrm{H}_{4} \mathrm{SiO}_{4}$ ) and some major cations in the bivariate plots of Fig. $4 \mathrm{a}$ and b. However, the concentration of $\mathrm{H}_{4} \mathrm{SiO}_{4}$ is up to two orders of magnitude lower than those of the $\mathrm{Na}^{+}$ and $\mathrm{Ca}^{+2}$, which suggests that some other minerals, more soluble than plagioclase, are also contributing these ions to the water. In addition, cation exchange (Eq. (2)) can control the concentration of these ions in water.

$2 \equiv \mathrm{X}-\mathrm{Na}+\mathrm{Ca}^{2+}=\equiv \mathrm{X}_{2}-\mathrm{Ca}+2 \mathrm{Na}^{+}$

where $\equiv \mathrm{X}$ - represents an exchange site in clay minerals. Cation exchange is a common process in sedimentary basins where clay minerals are abundant, and it has been widely considered as an important factor controlling the concentration of $\mathrm{Na}^{+}$and $\mathrm{Ca}^{+2}$ in aquifers of the Chacopampean plain (e.g., García et al., 2001; García et al., 2007; Carol et al., 2012). In agreement, all data (in meq $\mathrm{L}^{-1}$ ) in Fig. 5 plot close to the line with a -1 slope, indicating that the excess of $\mathrm{Na}^{+}$can partially be released from exchange sites in clay minerals due to the preferential adsorption of the excess of alkaline-earth ions. The Na-Cl signature of groundwater in loess plain (in the more continental sector of the coastal plain) is due to the regional groundwater flow (Carol et al., 2013). On the other hand, in all cases, the superficial water samples present isotopic enrichments associated with little or no increase in ionic content, with typical evaporation tendencies.

Elevated concentrations of $\mathrm{V}$ and concentrations of As that exceed the national guideline for drinking water $\left(0.01 \mathrm{mg} \mathrm{L}^{-1}\right.$; CAA, 2012) were measured in groundwater of the study area. The presence of these elements in water is associated to geogenic contaminants (Nicolli et al., 2012; Borgnino et al., 2013; Garcia et al., 2014), as they are released to the water during the alteration of volcanic glass shards spread in the loessic sediments (i.e., Bia et al., 2015) and subsequently adsorbed onto Fe (hydr)oxide coatings (Garcia et al., 2014). However, these ions may be rapidly desorbed due to the predominating alkaline conditions in groundwater of the region (Garcia et al., 2014). Conversely, in the petrochemical sector, high concentrations of trace elements such as As, 


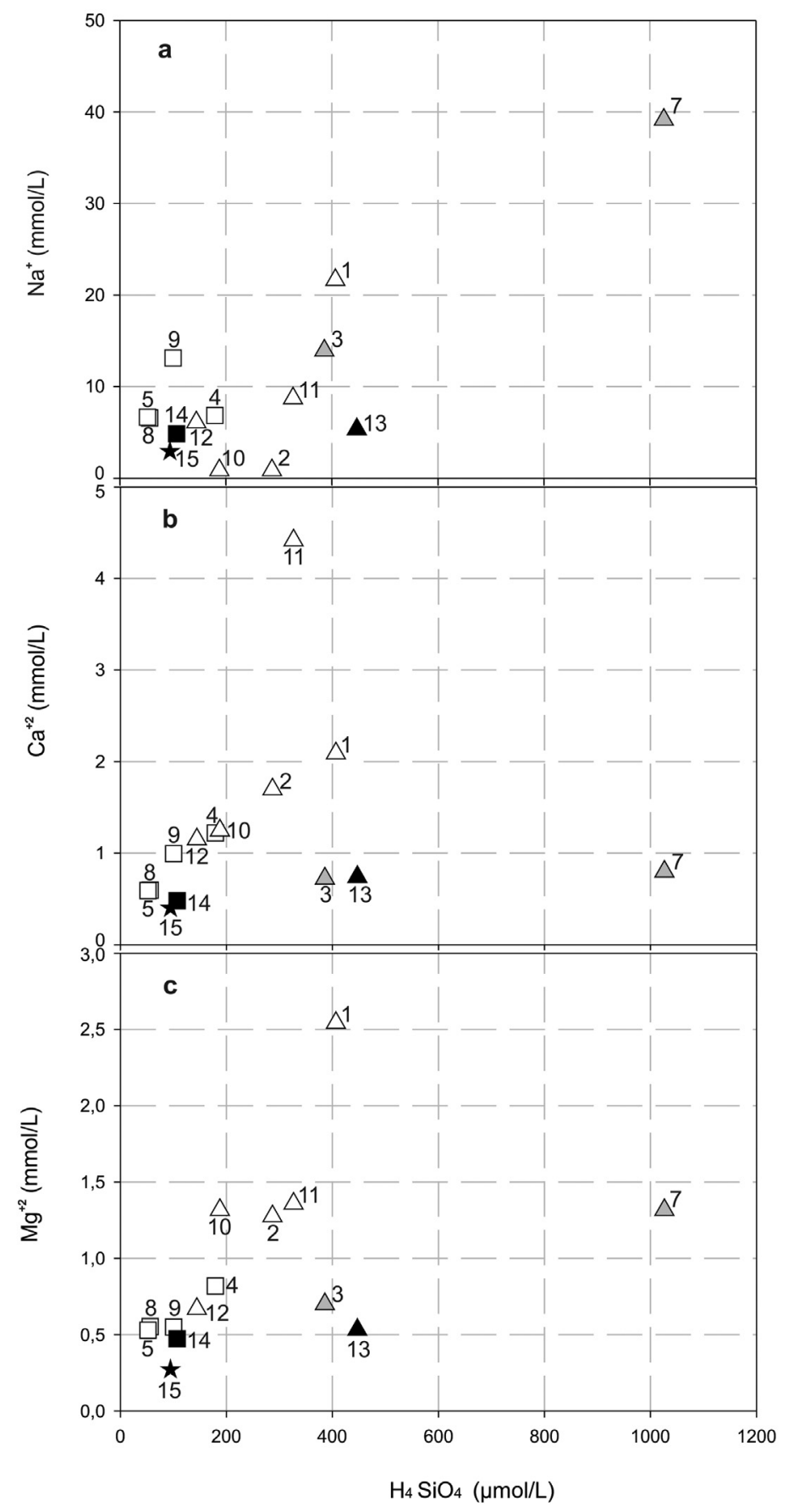

Petrochemical pole surface water

$\triangle \begin{aligned} & \text { Petrochemical pole } \\ & \text { groundwater (5m depth) }\end{aligned}$

$\triangle$ Petrochemical pole groundwater (16m depth)

Punta Lara Reserve surface water

Punta Lara Reserve groundwater

Río de la Plata

Fig. 4. Bivariate plots showing the ratios (a) $\mathrm{H}_{4} \mathrm{SiO}_{4}$ and sodium; (b) $\mathrm{H}_{4} \mathrm{SiO}_{4}$ and calcium and (c) $\mathrm{H}_{4} \mathrm{SiO}_{4}$ and magnesium in samples of the study area (chemical data in Table 1).

$\mathrm{V}, \mathrm{Mn}$, and $\mathrm{Cr}$ as well as $\mathrm{SO}_{4}{ }^{-2}, \mathrm{Na}^{+}$and $\mathrm{HCO}_{3}{ }^{-}$(Fig. $6 \mathrm{c}$, $\mathrm{d}$ and e) are mostly associated with punctual sources of anthropic contamination. A clear evidence of such type of contamination was observed in topsoils near an ancient sulfuric acid plant close to Este canal. As shown in Fig. 7, abundant clasts of sulfur and gypsum of about $15 \mathrm{~mm}$ in diameter are spread over the surface and are liable to be dissolved by rainwater contributing elevated concentrations of $\mathrm{SO}_{4}{ }^{-2}, \mathrm{Na}^{+}$and $\mathrm{HCO}_{3}{ }^{-}$to the water. High concentrations of dissolved $\mathrm{Mn}$ and $\mathrm{Cr}$ still persist downflow in response to the leaking of effluents from point sources of contamination (sample 11) but the contents of $\mathrm{SO}_{4}{ }^{-2}, \mathrm{Na}^{+}$ and $\mathrm{HCO}_{3}{ }^{-}$tend to decrease. Near the Oeste canal in the petrochemical pole, surface and groundwater samples contain high concentrations of 

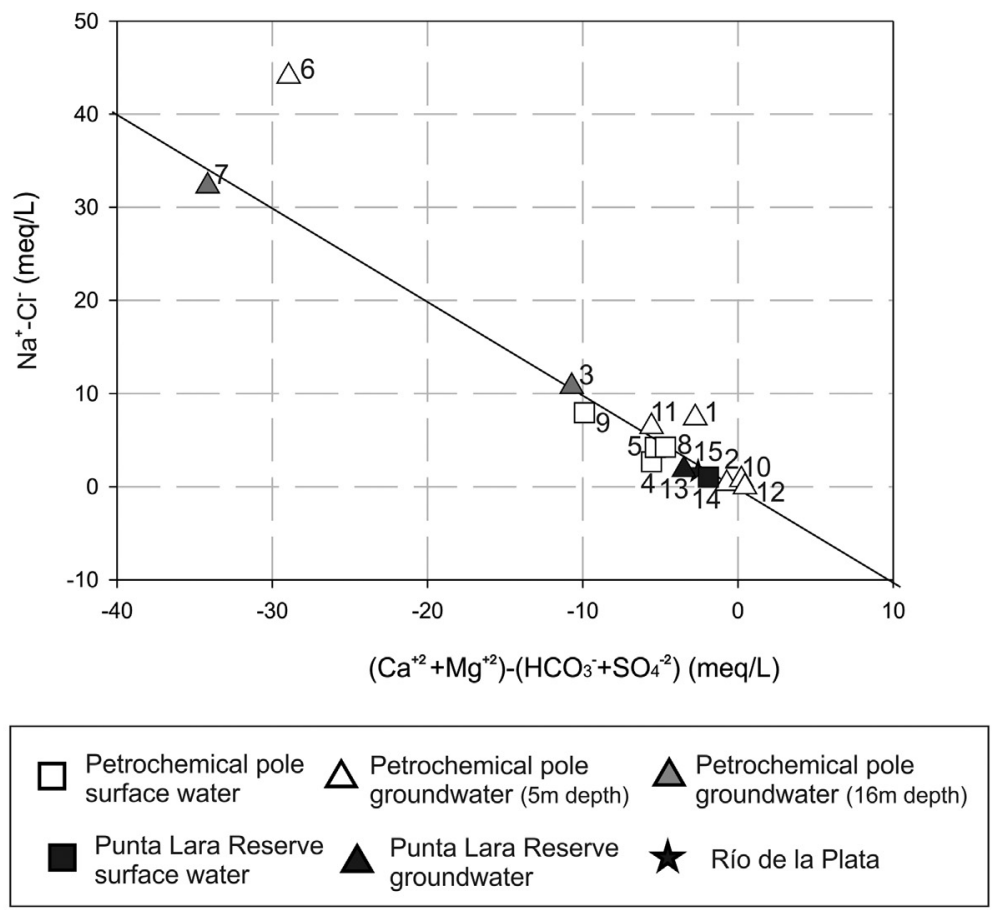

Fig. 5. Ratio $\left(\mathrm{Ca}^{2+}+\mathrm{Mg}^{2+}\right)-\left(\mathrm{HCO}_{3}{ }^{-}-\mathrm{SO}_{4}{ }^{2-}\right)$ vs. $\left(\mathrm{Na}^{+}-\mathrm{Cl}^{-}\right)$in water samples of the study area.

Zn but they are rather below the guideline value set by the Argentinean regulations (5.0 $\mathrm{mg} \mathrm{L}^{-1}$; CAA, 2012). Similarly, groundwater samples collected from the coastal levee near the petrochemical pole showed concentrations of $\mathrm{Mn}$ exceeding the national guideline requirements for drinking water (0.1 $\mathrm{mg} \mathrm{L}^{-1}$; CAA, 2012), while the concentration of $\mathrm{Cu}$ measured in the coastal levee was nearly one order of magnitude higher than those determined in the remaining samples of the petrochemical pole. Anthropic contamination in this case only affects the concentrations of some trace metals, but the isotopic and major chemical composition defined for the more littoral areas of the coastal plain is preserved.

The heterogeneities in the chemical composition and trace element contents in groundwater of the petrochemical pole are the result of the confluence of several sources of pollution. However, the spatial extension of the resulting contamination plumes is rather limited due to the low hydraulic gradient in the area (in the order of $10^{-4}$ ). In addition, the extent of groundwater discharge into surface water seems to be low in view of the differences in the chemical and isotopic signatures between surface and groundwater samples. In general, water accumulated in the canals of the petrochemical pole is of the $\mathrm{Na}-\mathrm{HCO}_{3}$ type and its isotopic signature reveals contributions from rainfall and from the Río de la Plata, as well as intense evaporation due to low flow velocities. In the Conclusión canal, for example, the isotopic signature is that of the local rainfall because this canal receives runoff discharges from nearby urbanized areas. Moreover, in the Este canal water contributions are from rainfall but also from high tidal flow events that trigger the input of water from the Río de la Plata. Water stored in the Este canal is slowly evacuated due to the low hydraulic gradient and therefore remains exposed to intense evaporation as revealed by their isotopic signature.

In summary, the petrochemical pole located in the western coastal plain of the Río de la Plata estuary has modified the hydrodynamics of the area through piping and land filling actions. These changes along with leaking of effluent derived from industrial activity, resulted in modifications on the chemistry of surface and groundwater in this sector of the coastal plain. Human impact is evidenced by the occurrence of large variations in the major chemical composition of water, and also by the elevated concentrations of some trace elements that are not contributed from natural sources. The infiltration of wastes derived from industrial activity is the more likely source of the increased concentrations of $\mathrm{SO}_{4}{ }^{-2}, \mathrm{HCO}_{3}{ }^{-}, \mathrm{Na}^{+}$and also of $\mathrm{Zn}, \mathrm{Cu}$, $\mathrm{Mn}$ and $\mathrm{Cr}$ measured in some boreholes of the area. Likewise, natural sources of As and V (volcanic ash spread in loessic sediments) contribute high concentrations of these elements to water. The obtained results characterize the impact of the petrochemical industry on the inorganic chemical composition of surface and groundwater in a coastal plain environment. To identify the signs of incipient contamination and to understand the mechanisms that control the distribution of inorganic contaminants between the sediments and the water are key for designing adequate management guidelines for local conditions but also applicable to some other areas with similar features.

\section{Acknowledgements}

The authors are very indebted to the Agencia Nacional de Promoción Científica y Tecnológica (National Agency for Scientific and Technological Promotion), the Consejo Nacional de Investigaciones Científicas y Técnicas (National Council for Scientific and Technological Research), and the Universidad Nacional de La Plata (National University of La Plata) of Argentina for financially supporting this study by means of their grants, PICT $2013-2248$ and PID N782. L. Santucci acknowledges a doctoral fellowship from CONICET. E. Carol and M.G. Garcia are members of CICyT in Argentina's CONICET. We are especially grateful to the anonymous reviewer that suggested significant improvements to this manuscript. 
ARTICLE IN PRESS

L. Santucci et al.

Marine Pollution Bulletin $x x x(x x x x) x x x-x x x$
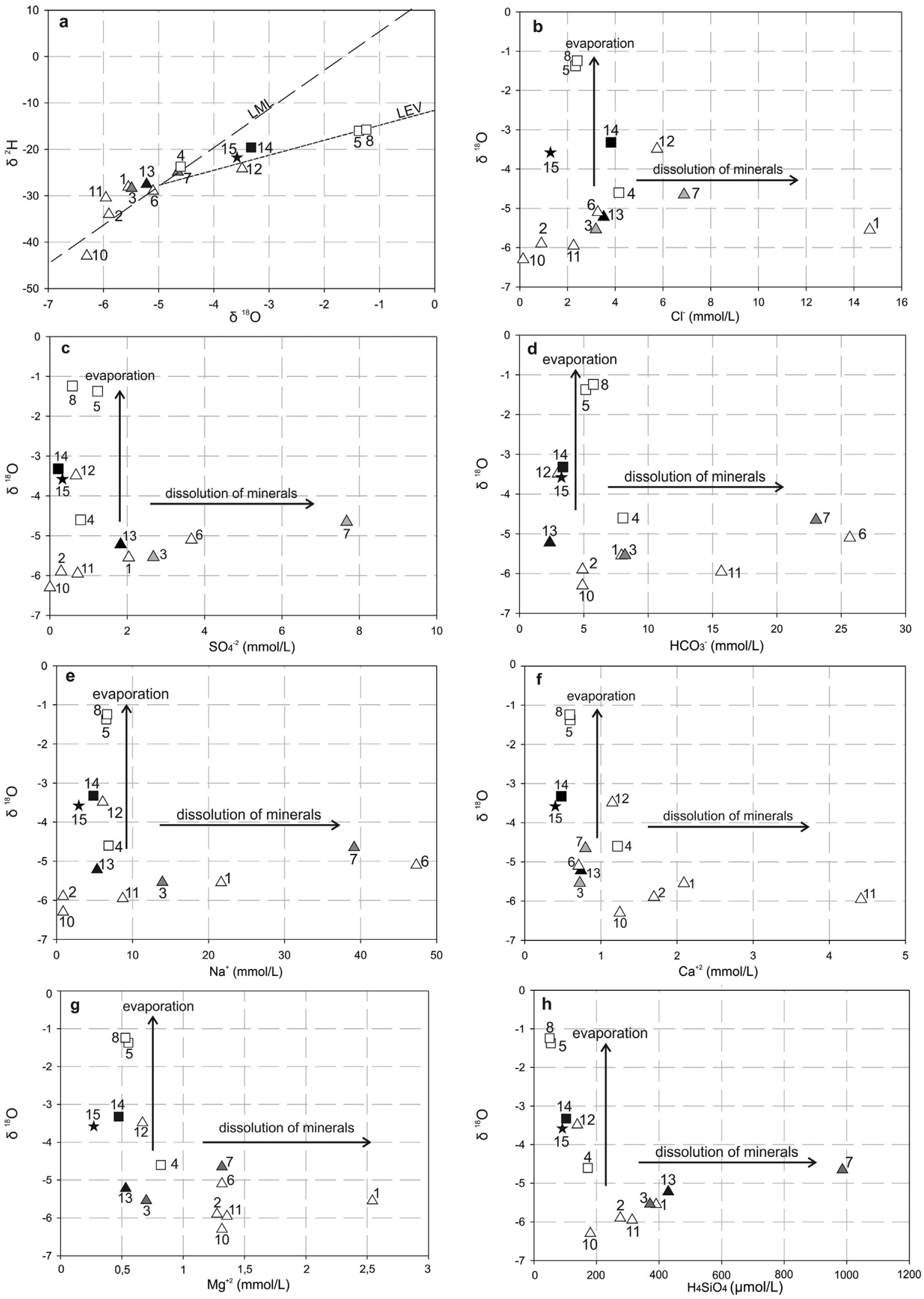
Petrochemical pole
surface water $\Delta_{\text {groundwater (Sm depth) }}^{\text {Petrochemical pole }} \Delta \begin{aligned} & \text { Petrochemical pole } \\ & \text { groundwater (16m depth) }\end{aligned}$

Punta Lara Reserve

surface water
Punta Lara Reserve groundwater

Fig. 6. Relation of (a) $\delta^{2} \mathrm{H}$ vs. $\delta^{18} \mathrm{O}$ and (b to h) $\delta^{18} \mathrm{O}$ vs. ions.

8 


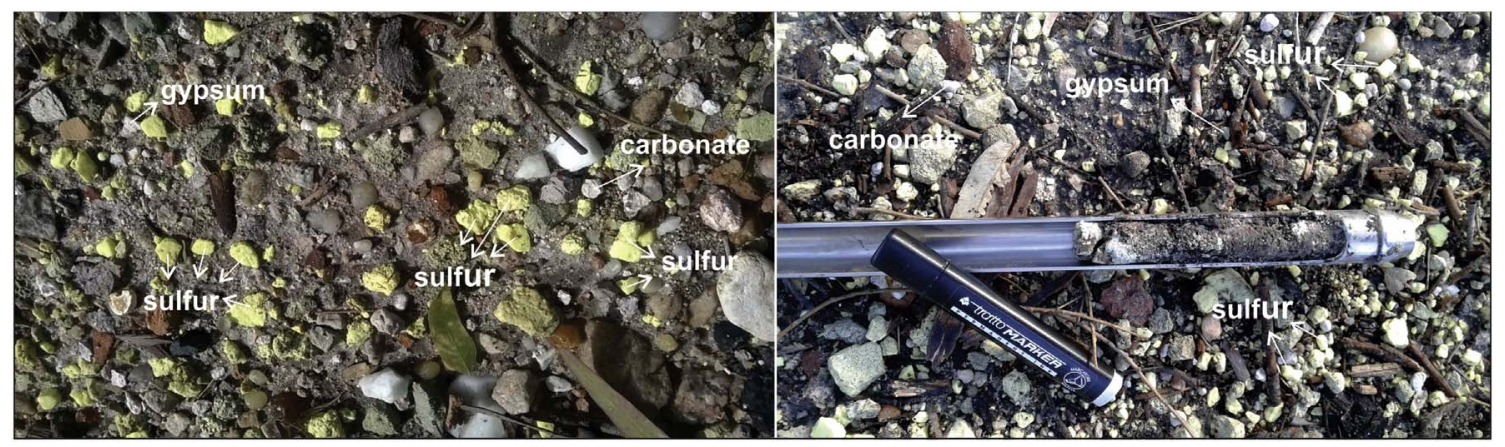

Fig. 7. Clastic grains of sulfur, gypsum and carbonate in topsoils affected by wastes of a sulfuric acid plant.

\section{References}

APHA (American Public Health Association), 1998. Standard Methods for the Examination of Water and Wastewater, 20th ed. American Public Health Association, American Water Works Association, Water Environment Federation, Washington, DC.

Bia, G., Borgnino, L., Gaiero, D.M., Garcia, M.G., 2015. Arsenic-bearing phases in South Andean volcanic ashes: implications for As mobility in aquatic environments. Chem. Geol. 393-384, 26-35.

Borgnino, L., Garcia, M.G., Bia, G., Stupar, Y.V., Le Coustumer, P., Depetris, P.J., 2013. Mechanisms of fluoride release in sediments of Argentina's central region. Sci. Total Environ. 443, 245-255.

Botté, S.E., Freije, R.H., Marcovecchio, J.E., 2010. Distribution of several heavy metals in tidal flats sediments within Bahía Blanca Estuary (Argentina). Water Air Soil Pollut. 210, 371-388.

CAA Código Alimentario Argentino, 2012. Capitulo XII. Bebidas Hídricas, Agua y Agua Gasificada. Artículo 982. Res Conj. SPRyRS y SAGPyA Nº 68/2007 y Nº 196/2007. Ley 18284. Marzocchi, Buenos Aires.

Carol, E.S., Kruse, E.E., 2012. Hydrochemical characterization of the water resources in the coastal environments of the outer Río de la Plata estuary, Argentina. J. S. Am. Earth Sci. 37, 113-121.

Carol, E., Kruse, E., Mas Pla, J., 2009. Hydrochemical and isotopical evidence of groundwater salinization processes on the coastal plain of Samborombón Bay, Argentina. J. Hydrol. 365, 335-345.

Carol, E., Kruse, E., Laurencena, P., Rojo, A., Deluchi, M., 2012. Ionic exchange in groundwater hydrochemical evolution. Study case: the drainage basin of El Pescado creek (Buenos Aires province, Argentina). Environ. Earth Sci. 65, 421-428.

Carol, E., Kruse, E., Mancuso, M., Melo, M., 2013. Local and regional water flow quantification in groundwater-dependent wetlands. Water Resour. Manag. 34, $26-32$.

Da Lio, C., Carol, E., Kruse, E., Teatini, P., Tosi, L., 2015. Saltwater contamination in the managed low-lying farmland of the Venice coast, Italy: an assessment of vulnerability. Sci. Total Environ. 533, 356-369.

Da, C., Liu, G., Yuan, Z., 2014. Analysis of HCHs and DDTs in a sediment core from the Old Yellow River estuary, China. Ecotoxicol. Environ. Saf. 100, 171-177.

Dapeña, C., Panarello, H.O., 2004. Composición isotópica de la lluvia de Buenos Aires. Su importancia para el estudio de los sistemas hidrológicos pampeanos. Rev. Lat. Am. Hyidrogeol. 4, 17-25.

García, M.G., Hidalgo, M., Del, V., Blesa, M.A., 2001. Geochemistry of groundwater in the alluvial plain of Tucumán, Argentina. Hydrogeol. J. 9, 597-610.

García, M.G., Sracek, O., Fernández, D.S., Hidalgo, M., 2007. Factors affecting arsenic mobilization in groundwaters from northwestern Chaco-Pampean plain, Argentina. Environ. Geol. 52, 1261-1275.

Garcia, M.G., Borgnino, L., Bia, G., Depetris, P.J., 2014. Mechanisms of arsenic and fluoride release from Chacopampean sediments (Argentina). Int. J. Environ. Health 7, 41-57.

Gonfiantini, 1978. Standards for stable isotope measurements in natural compounds. Nature 271, 534-536.

Graber, E.R., Laor, Y., Ronen, D., 2008. Aquifer contamination by chlorinated-VOCs: the case of an urban metropolis megasite overlying the Coastal Plain aquifer in Israel. Hydrogeol. J. 16, 1615-1623.

Güler, C., Kurt, M.A., Alpaslan, M., Akbulut, C., 2012. Assessment of the impact of anthropogenic activities on the groundwater hydrology and chemistry in Tarsus coastal plain (Mersin, SE Turkey) using fuzzy clustering, multivariate statistics and
GIS techniques. J. Hydrol. 414, 435-451.

Herlinger Jr., R., Viero, A.P., 2007. Groundwater vulnerability assessment in coastal plain of Rio Grande do Sul State, Brazil, using drastic and adsorption capacity of soils. Environ. Geol. 52, 819-829.

Kind, V.M., 2004. Desplazamiento del frente de salinidad del Río de la Plata debido al aumento del nivel medio del mar. (Doctoral dissertation, Tesis de grado) Facultad de Ingeniería (FI), Universidad de Buenos Aires (UBA).

La Colla, N., Negrin, V., Marcovecchio, J.E., Botté, S.E., 2015. Dissolved and particulate metals dynamics in a human impacted estuary from the SW Atlantic. Estuar. Coast. Shelf Sci. 166, 45-55.

Logan, W., Nicholson, R., 1998. Origin of dissolved groundwater sulphate in coastal plain sediments of the Rio de la Plata, Eastern Argentina. Aquat. Geochem. 3, 305-328.

Logan, W., Rudolph, D., 1997. Microdepressión-focused recharge in a coastal wetland, La Plata, Argentina. J. Hydrol. 194, 221-238.

Logan, W.S., Auge, M.P., Panarello, H.O., 1999. Bicarbonate, sulfate, and chloride water in a shallow, clastic-dominated coastal flow system, Argentina. Ground Water 37, 287-295.

López-Lanús, B., Marino, G.D., 2010. El charlatán (Dolichonyx oryzivorus) en América: Un resumen sobre la ecología y conservación de un viajero. En 11-15. In: López-Lanús, B., Marino, G.D. (Eds.), Aportes al conocimiento de la ecología del Charlatán y su estado actual en la Provincia de Santa Fe, Argentina. Temas de Naturaleza y Conservación, Monografía de Aves Argentinas N 7 (Buenos Aires, Argentina).

Marcovecchio, J.E., Botté, S.E., Fernandez Severini, M., Delucchi, F., 2010. Geochemical control of heavy metal concentrations and distribution within Bahía Blanca Estuary (Argentina). Aquat. Geochem. 16, 251-266.

Nicolli, H.B., Bundschuh, J., Blanco, M.D.C., Tujchneider, O.C., Panarello, H.O., Dapena, C., Rusansky, J.E., 2012. Arsenic and associated trace-elements in groundwater from the Chaco-Pampean plain, Argentina: results from 100 years of research. Sci. Total Environ. 429, 36-56.

Panarello, H.O., Dapeña, C., 2009. Large scale meteorological phenomena, ENSO and ITCZ, define the Paraná River isotope composition. J. Hydrol. 365, 105-112.

Pruden, A., Pei, R., Storteboom, H., Carlson, K.H., 2006. Antibiotic resistance genes as emerging contaminants: studies in northern Colorado. Environ. Sci. Technol. 40, 7445-7450.

Sá, F., Sanders, C.J., Patchineelam, S.R., da Costa Machado, E., Lombardi, A.T., 2015. Arsenic fractionation in estuarine sediments: does coastal eutrophication influence As behavior? Mar. Pollut. Bull. 96, 496-501.

Schnack, E., Isla, F., De Francesco, F., Fucks, E., 2005. Estratigrafía del Cuaternario Marino Tardío en la Provincia de Buenos Aires. In: De Barrio, R., Etcheverry, R., Caballé, M., Llambías, E. (Eds.), Geología y Recursos Minerales de la provincia de Buenos Aires, $16^{\circ}$ Congreso Geológico Argentino, Relatorio 159-182, La Plata.

Vandenbohede, A., Lebbe, L., 2012. Groundwater chemistry patterns in the phreatic aquifer of the central Belgian coastal plain. Appl. Geochem. 27, 22-36.

Vecchioli, G.I., 1998. Degradación de mezclas complejas de hidrocarburos en suelo. (Trabajo de tesis) Universidad Nacional de La Plata, La Plata, Argentina.

Wu, G., Shang, J., Pan, L., Wang, Z., 2014. Heavy metals in surface sediments from nine estuaries along the coast of Bohai Bay, Northern China. Mar. Pollut. Bull. 82, 194-200.

Zhu, Y.-G., Zhao, Y., Li, B., Huang, C.-L., Zhang, S.-Y., Yu, S., Chen, Y.-S., Zhang, T. Gillings, M.R., Su, J.-Q., 2017. Continental-scale pollution of estuaries with antibiotic resistance genes. Nat. Microbiol. 2, 16270. 